\title{
aniki
}

Revista Portuguesa da Imagem em Movimento

Portuguese Journal of the Moving Image

\section{O filme Reparação e o debate sobre a luta armada como veículo para o antipetismo no cinema brasileiro contemporâneo Wallace Andrioli Guedes ${ }^{1}$}

\section{Introdução}

O presente artigo analisa o documentário Reparação (2010), de Daniel Moreno, à luz da história das abordagens fílmicas da ditadura militar brasileira (1964-1985) e da experiência da luta armada nesse período, e compreende o filme como portador de um discurso pouco frequente no cinema sobre tais temas. É igualmente importante considerar aqui a emergência recente de uma produção cinematográfica ideologicamente posicionada à direita no espectro político brasileiro, vinculada ao sentimento de rechaço ao Partido dos Trabalhadores (PT), que governou o país entre 2003 e 2016, consolidado em determinadas parcelas da sociedade. Reparação e seu diretor se encontram bastante alinhados a essa postura.

Reparação tem como objetivo principal discutir alguns casos de pessoas que, durante o período ditatorial, foram de alguma forma atingidas por ações das esquerdas revolucionárias que lutavam contra o regime. Nesse sentido, trata-se de um filme que destoa bastante da maioria dos documentários produzidos, desde a década de 1970, sobre a luta armada e as vítimas da ditadura militar, geralmente interessados em colher depoimentos sobre as violências sofridas pelos ex-guerrilheiros no cárcere. Os que são considerados vítimas nesses filmes são reposicionados por Daniel Moreno como algozes em Reparação.

No que concerne ao referencial teórico-metodológico, buscase reconhecer a necessidade de o historiador estar atento aos elementos próprios da linguagem cinematográfica (montagem, enquadramento, mise-en-scène, trilha sonora, etc.) como construtores dos discursos fílmicos. Dessa forma, a análise pede que, conforme aponta Marc Ferro (2010, 32), se parta das imagens: "Não buscar nelas somente ilustração, confirmação ou o desmentido do outro saber que é o da tradição escrita. Considerar as imagens como tais, com o risco de apelar para outros saberes para melhor compreendê-las". Já David Bordwell (2008, 69) entende que os fatores externos aos filmes devem ser, claro, considerados, mas que aqueles mais distantes do cotidiano da produção, "tais como fortes pressões culturais ou demandas políticas”, se manifestam

\footnotetext{
${ }^{1}$ Universidade Federal de Juiz de Fora, Rua José Lourenço Kelmer s/n, 36036-900 - São Pedro, Juiz de Fora - MG, Brasil.
} 
diretamente apenas em escolhas concretas, sobretudo nas formas como o realizador dialoga com a tradição de cinema na qual se inscreve sua obra.

No caso de Reparação, interessa aqui inseri-lo num histórico de olhares cinematográficos para determinada temática (a luta armada contra a ditadura militar brasileira) e compreendê-lo dentro de um contexto político bastante específico (de crescimento das oposições aos governos do PT), que, dados os posicionamentos assumidos publicamente por seu diretor, contamina diretamente o discurso fílmico. Por isso, no presente artigo os elementos mais diretamente referidos à linguagem do cinema são considerados perifericamente, recaindo maior atenção sobre as relações de Reparação tanto com a tradição do cinema documentário no Brasil, quanto, principalmente, com a política contemporânea.

\section{Um breve histórico}

É possível acompanhar a construção de um histórico da abordagem do tema da luta armada no cinema brasileiro, que tem início já na segunda metade da década de 1960, em filmes de ficção como $O$ desafio (1965) e Terra em transe (1967), que vislumbraram, em seus respectivos epílogos, o enfrentamento revolucionário como uma saída para as esquerdas após a derrota representada pelo golpe civilmilitar de 1964. No entanto, foi no período de transição para a democracia, em fins da década de 1970 e inícios da de 1980, que esse tema começou a aparecer de forma mais aberta no cinema.

Nesse momento, alguns filmes foram produzidos com uma visão mais crítica da experiência da guerrilha, afinados com o discurso apaziguador e de reintegração dos ex-militantes revolucionários à sociedade e à política institucional brasileiras, que granjeava espaço a partir da promulgação da Lei da Anistia (1979). Pra frente Brasil (1982), de Roberto Farias, e O bom burguês (1983), de Oswaldo Caldeira, são os principais exemplos aqui.

O primeiro narra a história de Jofre (Reginaldo Faria), cidadão de classe média que, tido por "terrorista", é sequestrado por um grupo de extrema-direita que passa a torturá-lo barbaramente, enquanto sua família busca notícias de seu paradeiro. O pano de fundo é a Copa do Mundo de futebol de 1970, com a população embalada e envolvida pelas sucessivas vitórias da Seleção. Há no filme de Farias personagens ligados à guerrilha: Mariana (Elizabeth Savalla), namorada de Miguel (Antônio Fagundes), irmão de Jofre; e dois outros membros da organização da qual esta personagem faz parte, Ivan e Zé Roberto (Luiz Mário Farias). Apresentados como jovens sonhadores, mas vazios de conteúdo, os guerrilheiros têm importância na trama de Pra frente Brasil por contribuírem para a vingança de Miguel contra os algozes de seu irmão. No entanto, eles representam o outro extremo das torturas bárbaras cometidas pelos 
vilões do filme (liderados pelo temível Dr. Barreto), um extremo também violento e que, por isso, deve ser igualmente extirpado. Assim, ao final da narrativa de Farias, tanto torturadores cruéis quanto militantes radicais de esquerda são mortos, restabelecendo o equilíbrio perdido e pedido, de acordo com o filme, pelo país. Nesse sentido, o discurso político de Pra frente Brasil se afina com o texto do letreiro - escrito por Farias a pedido da censura, como condição para liberação da obra - que abre a narrativa:

Este filme se passa durante o mês de junho de 1970, num dos momentos mais difíceis da vida brasileira. Nessa época, os índices de crescimento apontavam um desempenho extraordinário no setor econômico. No político, no entanto, o governo empenhava-se na luta contra o extremismo armado. De um lado, a subversão da extrema esquerda, de outro, a repressão clandestina. Sequestros, mortes, excessos. Momentos de dor e aflição. Hoje, uma página virada na história de um país que não pode perder a perspectiva do futuro. Pra frente Brasil é um libelo contra a violência.

O personagem Miguel, que pega em armas para enfrentar não só o grupo de Barreto, mas também seu ex-patrão Geraldo Braulen empresário que financia o combate clandestino à "subversão" -, é visto com bons olhos pelo roteiro de Farias, já que suas motivações são puramente passionais, não estando contaminadas por quaisquer pressupostos ideológicos. Miguel empreende uma busca por justiça e, posteriormente, vingança, tema clássico no cinema hollywoodiano, que conduz o personagem a um duelo típico do gênero western no epílogo de Pra frente Brasil.

O bom burguês acompanha a inusitada trajetória de Lucas (José Wilker), bancário que desvia dinheiro de seu emprego para financiar a guerrilha, enquanto constrói uma fachada de empresário bemsucedido - o que o leva a envolver-se também com a repressão clandestina aos mesmos guerrilheiros que financia. Como Pra frente Brasil, O bom burguês pinta um retrato dúbio da luta armada. Seus membros parecem dotados de boas intenções, seja no caso de figuras mais jovens e inocentes, como Joana (Cristiane Torloni) e Lauro (Anselmo Vasconcelos), seja no de líderes, como Joel (Ivan de Almeida) e Raul (Nelson Xavier). No entanto, o filme também destaca o caráter autoritário da organização guerrilheira retratada, que acaba por sufocar a individualidade do casal Joana e Lauro e determinar a morte da primeira. Joana tem suprimidas suas relações familiares (é duramente criticada por seus companheiros de luta por ter fraquejado durante a ação em um banco, ao ter se deparado com seu irmão Lucas) e sua alegria da juventude (ela tem um raro momento de leveza quando retorna ao apartamento no qual morava com uma amiga universitária); Lauro tem de se contentar a lembrar de sua infância através das frestas do sótão do esconderijo utilizado pela organização, por onde observa algumas crianças soltando pipa. 
Também como em Pra frente Brasil, os guerrilheiros de $O$ bom burguês, ao menos os que ganham mais destaque, acabam punidos com a morte: Joana comete suicídio para não denunciar o próprio irmão à repressão; Lauro é preso e brutalmente torturado, revelando a identidade da namorada e depois sumindo de cena (Thomas, o empresário que financia a tortura, interpretado por Jardel Filho, chega a prometer a Joana que ele ainda está vivo, mas não sabemos, ao término do filme, se o personagem fora sincero em sua fala); Raul é assassinado.

Em depoimento presente no DVD de O bom burguês, Caldeira explicitou o olhar crítico de seu filme para a esquerda armada:

O filme mostra que alguns revolucionários, algumas pessoas que estão engajadas em organizações de esquerda pretensamente revolucionárias, eram ou são muito parecidas com seus antagonistas de direita. (...) O filme questionava certas atitudes, certos comportamentos e certas ações da esquerda. Questionava através, claramente, de alguns personagens. Isso é uma coisa também que causou estranhamento. Uma coisa que depois voltou, virou café pequeno, todo mundo passou a criticar, inclusive aí com tons de direita. O nosso filme, na época, em plena ditadura, criticava não só a ditadura militar, como a própria ação de esquerda.

Ambos os longas-metragens, portanto, condenam a opção pelas armas, aproximando a extrema-esquerda da extrema-direita em suas práticas violentas - ainda que se referindo aos militantes da primeira vertente como ingênuos, vazios e dotados de boas intenções, enquanto os da segunda são tratados como vilões absolutos.

Já no contexto do cinema da Retomada, na década de 1990, ganham destaque dois filmes com visões distintas sobre a luta armada: Lamarca (1994), de Sergio Rezende, e $O$ que é isso, companheiro? (1997), de Bruno Barreto. O primeiro, cinebiografia do capitão do Exército Brasileiro que, em 1969, desertou para se engajar na guerrilha contra a ditadura militar, apresenta, de acordo com Oricchio $(2004,113)$, as organizações revolucionárias sob um prisma crítico, já que marcadas pela derrota voluntarista; mas, ainda assim, trata Carlos Lamarca como herói nacional, associando imageticamente seu martírio ao calvário de Cristo.

O segundo, adaptação ficcional do livro homônimo de Fernando Gabeira, se propõe falar do sequestro do embaixador norte-americano Charles Elbrick, em 1969, por organizações da esquerda armada brasileira. O filme causou polêmica quando de seu lançamento nos cinemas, particularmente pelo tratamento dispensado à luta armada e aos torturadores. Barreto e o roteirista Leopoldo Serran apostaram em apresentar a guerrilha de esquerda como um empreendimento de velhos militantes inescrupulosos particularmente, o personagem Jonas (Matheus Nachtergaele), responsável pelo comando do sequestro, antipático ao protagonista 
do filme (com o qual o público deve se identificar) e aparentemente sedento pela chance de assassinar o sequestrado -, que manipulam jovens rebeldes ingênuos e sonhadores. Já Elbrick, no cativeiro em meio a esses jovens, aparece como voz da razão, homem experiente e sábio que se contrapõe, enquanto tal, à loucura comandada pelos militantes mais velhos. Para complicar um pouco mais, O que é isso, companheiro? ainda traz a figura de um torturador (Marco Ricca) que passa longe da crueldade per se, que caracterizava esse tipo de personagem em outros filmes sobre o período. O torturador de Barreto sofre com crises de consciência por suas ações, parecendo, assim, mais humano que o guerrilheiro Jonas, por exemplo.

Essa caracterização das organizações revolucionárias, na verdade, não é exatamente uma novidade, pois apareceu, com ênfase negativa ainda maior, no filme As armas (1969), de Astolfo Araújo, cujo protagonista, César, é um chofer que trabalha para uma organização de esquerda sobre a qual ele quase nada sabe. Ambicioso, o personagem se irrita com a pouca importância que lhe é dada no interior do grupo, passando paulatinamente ao enfrentamento com seus superiores. Ainda que César não seja um homem de boa índole (ele é apresentado pelo filme como egoísta, agindo violentamente com uma prostituta que recusa beijar-lhe a boca e armando algumas artimanhas para conquistar as mulheres que deseja, incluindo a filha do seu patrão), chama atenção a abordagem claramente negativa da esquerda armada. Os membros de tal organização são rudes no trato com o chofer e com outro funcionário mais velho - o que explicita seu elitismo e, no limite, justifica certas ações do protagonista. São também egoístas, imaturos e hipócritas. Vale citar duas passagens do filme que confirmam essa visão construída por Araújo.

$\mathrm{Na}$ primeira delas, César está em seu quarto assistindo ao noticiário, que fala da repressão violenta da polícia a manifestações estudantis. Aparentemente preocupado, o personagem se dirige ao líder da organização para relatar o ocorrido, mas a notícia é recebida com indiferença por este, que orienta César a não se preocupar, já que não se tratava do seu "pessoal". A esquerda radical de As armas não só deixa de participar de manifestações de rua, preferindo a conspiração inócua em ambientes privados, como se nega a solidarizar-se com aqueles que, tendo feito a opção pelo enfrentamento aberto com a ditadura em espaços públicos, sofrem com a repressão policial. Na segunda passagem, César, já em total discordância com os outros membros do grupo - e alvo da desconfiança destes -, decide espionar uma de suas reuniões, na qual toma conhecimento da existência de grande quantia de armas e dinheiro em posse dos militantes, que se preparam para uma revolução que nunca chega. Durante tal reunião, o tema do constante adiamento das ações armadas é levantado e o personagem Boris, braço direito do líder da organização, argumenta que não há motivos 
para preocupação, já que eles sempre brincaram de fazer revolução. Mais uma vez, a luta armada surge estigmatizada no filme, representada como brincadeira de jovens imaturos ou manipulação de adultos inescrupulosos e gananciosos.

No campo do cinema documental, também são encontrados exemplares sobre a ditadura militar desde o auge do regime. Você também pode dar um presunto legal (1971/2006), média-metragem dirigido por Sérgio Muniz, tem como tema a atuação dos esquadrões da morte e de seu membro mais famoso, o delegado do DOPS (Departamento de Ordem Política e Social) de São Paulo, Sérgio Paranhos Fleury, fortemente atuante na repressão política. No mesmo ano, foi produzido nos Estados Unidos Brazil, a report on torture (1971), de Haskell Wexler, estruturado sobre depoimentos de ex-guerrilheiros brasileiros que sobreviveram a torturas nos cárceres do país e se encontravam, naquele momento, exilados no Chile.

Como no caso do cinema ficcional, o período da transição para a democracia foi prolífico também em documentários cujos temas estão relacionados ao regime ditatorial que chegava ao fim. $\mathrm{Na}$ década de 1980, aquele que abordou mais diretamente o tema da tortura a participantes da luta armada foi Que bom te ver viva (1989), de Lúcia Murat. Ela própria uma sobrevivente da violência dos órgãos de repressão da ditadura militar, Murat reuniu depoimentos de outras mulheres que passaram por essa experiência, com suas falas sendo pontuadas por um monólogo da atriz Irene Ravache, alter-ego da diretora. É possível dizer que, até esse momento (final dos anos 1980), o cinema documental sobre a ditadura militar manteve postura relativamente positiva em relação à luta armada, frequentemente se interessando por ouvir seus ex-participantes, principalmente a respeito das violências que sofreram na prisão abordando-os, portanto, na posição de vítimas.

Talvez o primeiro documentário a criticar abertamente a opção pela luta armada tenha sido $O$ velho - A história de Luiz Carlos Prestes (1997), de Toni Venturi, realizado já no contexto da Retomada. Venturi utilizou depoimentos do próprio Prestes, de Fernando Gabeira e Ferreira Gullar para, no breve segmento do filme que trata do tema, fazê-lo com olhar bastante crítico. A fala de Gullar, mais forte entre as três, exemplifica bem isso:

Mas sucede é que, se eles, que desafiaram o regime, pra luta armada, tiveram essa repressão, os outros, que não desafiaram, tiveram também, que foram assassinados, foram torturados, foram liquidados. Sob a cobertura de que "é uma guerra e eles são a mesma coisa'. Eu me lembro de quando eu fui preso e o cara falar 'isso é farsa, vocês fazem a mesma coisa... eles são os companheiros de vocês e vocês fingem que um discorda de outro mas vocês estão na mesma'[...] Como pretexto de poder nos torturar e nos liquidar. Essa que é a verdade 
Alguns anos depois, Venturi realizou o longa-metragem ficcional Cabra-cega (2004), ambientado no período da ditadura militar e focado no processo de isolamento de um guerrilheiro, inspirado em Carlos Eugênio Paz, num "aparelho" clandestino. Tratase de um filme com olhar bem mais respeitoso em relação aos guerrilheiros, algo justificado pelo diretor por considerar superficial sua abordagem do tema em $O$ velho. ${ }^{2}$

Ainda assim, a maioria dos documentários produzidos sobre a luta armada e a ditadura desde então, inclusive no período que marca o boom do gênero no Brasil (a partir dos anos 2000), mantêm postura semelhante à de Que bom te ver viva: interessados nas narrativas dos ex-guerrilheiros sobre suas ações, as experiências no exílio e, principalmente, as violências sofridas quando capturados por agentes do regime. Vale citar alguns exemplos.

O primeiro deles, Hércules 56 (2006), de Sílvio Da-Rin, foi realizado como espécie de resposta a $O$ que é isso, companheiro?, ao que haveria de errado na maneira como o filme de Bruno Barreto apresenta a luta armada e a ação específica do sequestro do embaixador norte-americano em 1969. De acordo com Fernando Seliprandy Fernandes $(2013,56)$,

a película foi de fato acolhida por grande parte da crítica como a devida resposta documental às polêmicas ficcionalizações do filme $O$ que é isso, companheiro?, de Bruno Barreto. [...] Suas imagens traziam os rostos e as vozes das principais testemunhas do evento: de um lado, na rememoração coletiva das lideranças do sequestro; de outro, nos depoimentos individuais dos presos políticos libertados em troca de Elbrick.

No que concerne à luta armada, Hércules 56, para Fernandes, promove uma amenização das discordâncias sobre seu significado no contexto ditatorial, minimizando a derrota revolucionária no período, para ressaltar os frutos da luta colhidos a longo prazo: a democracia, os avanços políticos e sociais do país, etc., algo materializado na fala de Franklin Martins, um dos responsáveis pelo sequestro do embaixador norte-americano e entrevistado do filme: "Eu não tenho dúvidas de que o Brasil é muito melhor hoje do que era há 20 ou 30 anos. Foi porque sequestramos o embaixador americano? Não. Foi porque lutamos. O sequestro, captura, etc., foi um desses momentos de luta." O historiador conclui então que, "no fim, o tom geral do documentário é de celebração daquela ação armada como marco das conquistas presentes" (Fernandes, 2013, $60)$.

\footnotetext{
"Mostrei os guerrilheiros como seres falíveis, e não como caricaturas", diz Venturi. Folha de S. Paulo, 27 de março de 2005. Disponível em: http://www1.folha.uol.com.br/fsp/mais/fs2703200512.htm. Acesso em 13 de janeiro de 2018.
} 
Hércules 56 seria, para Fernandes, um documentário que trata o passado a partir de perspectiva monumental, baseada no apagamento, ou amenização, das tensões, visando à construção de uma cronologia coerente e coesa que justifica esse passado à luz do presente. Como contraponto a esse formato, o historiador analisa Diário de uma busca (2010), de Flávia Castro, que acompanha a busca da diretora pela história do pai, o ex-militante de esquerda Celso Castro, morto em condições misteriosas em 1984. O filme de Castro, ao contrário do de Da-Rin, introduz tensão no monumento da luta contra a ditadura no Brasil, já que seu pai/protagonista é um personagem que não se enquadrou na narrativa das esquerdas revolucionárias de reinserção na vida política democrática durante a abertura do início da década de 1980.

Diário de uma busca também aponta para uma tendência do cinema documentário brasileiro contemporâneo, inclusive aquele que tem a ditadura e a luta armada como temas: as narrativas em primeira pessoa, dotadas de tom intimista, geralmente conduzidas por um parente do biografado. São os casos também de Marighella (2012), de Isa Grinspum Ferraz, sobrinha do líder da Ação Libertadora Nacional (ALN); Em busca de Iara (2013), de Flávio Frederico, que acompanha a investigação pessoal de Mariana Pamplona, roteirista do filme, sobre a vida e a morte de sua tia Iara Iavelberg; Os dias com ele (2013), de Maria Clara Escobar, no qual a diretora segue a rotina de seu próprio pai, Carlos Henrique Escobar, intelectual preso e torturado na ditadura militar, submetendo-o a uma entrevista sobre o passado que por vezes se revela dolorosa.

\section{Reparação e a crítica à luta armada}

Reparação é um documentário bastante distante desse modelo. Tanto no que concerne à forma quanto à abordagem política do conteúdo. No primeiro aspecto, Daniel Moreno aposta num formato mais convencional, que Fernandes (2013, 60), em sua análise de Hércules 56, define como "documentário convencional de entrevista": "o entrevistado é enquadrado em ângulo mais ou menos frontal, o cineasta ficando fora de quadro; as vozes são fragmentadas em função da composição de uma narrativa linear e coerente; predomina o uso ilustrativo das imagens de arquivo".

É exatamente assim que Reparação está organizado: entrevistas fragmentadas com duas vítimas de ações da luta armada (Orlando Lovecchio e Marlio Jesus da Silva) e alguns "especialistas" no assunto (o historiador Marco Antonio Villa, o sociólogo Demétrio Magnoli, o ex-presidente Fernando Henrique Cardoso e Ipojuca Pontes, ex-secretário de cultura do governo Collor $^{3}$ ) que compõem

\footnotetext{
${ }^{3}$ Vale observar que nenhum dos "especialistas" entrevistados por Moreno é, de fato, pesquisador do tema da ditadura militar brasileira. Villa é quem mais se aproxima disso, tendo publicado um livro sobre o ex-presidente João Goulart
} 
uma narrativa politicamente coerente sobre a luta armada e a ditadura militar brasileira, complementadas por imagens de arquivo ilustrativas das afirmações dos depoentes (no caso, manchetes de jornais sobre o atentado que vitimou Lovecchio, a ficha policial do irmão de Silva, fotografias das Ligas Camponesas e do ex-presidente João Goulart e de um decreto assinado por ele no célebre Comício da Central de 13 de março de 1964, quando Villa se refere a tais personagens e episódios históricos).

O discurso político coerente que Reparação tenta construir é o de que a luta armada se tratava de um conjunto de organizações profundamente autoritárias, terroristas, influenciadas pela ideologia advinda de regimes ditatoriais considerados por Moreno ainda mais brutais que aquele instalado no Brasil (casos do cubano e do soviético).

O autoritarismo da esquerda armada brasileira e suas relações sobretudo com Cuba vem sendo analisado pela historiografia já há algum tempo. Denise Rollemberg (2001), por exemplo, se dedicou a estudar o treinamento militar de guerrilheiros brasileiros no país caribenho nas décadas de 1960 e 1970. Já Daniel Aarão Reis (2004; 2014), ao analisar os processos de reconstrução memorial durante a abertura política, destacou a não filiação das organizações da luta armada a valores democráticos:

Um primeiro deslocamento de sentido, promovido pelos partidários de uma ampla anistia, apresentou as esquerdas revolucionárias como parte integrante da resistência democrática, uma espécie de braço armado dessa resistência. Apagou-se, assim, o caráter revolucionário da proposta que havia moldado aquelas esquerdas. Ou seja, apagou-se o fato de que eram partidárias de uma ditadura revolucionária para efetuar as transformações radicais, essenciais à construção de uma sociedade livre da exploração e da opressão. Do ponto de vista histórico, não havia aí nada de inusitado ou excepcional, pois os modelos revolucionários do século XX haviam desembocado, realmente, em experiências ditatoriais. (Reis, 2014, 133-134)

No entanto, o tom adotado em Reparação é outro, bem mais agressivo, manifesto especialmente nas intervenções de Villa e Pontes. O primeiro ressalta o suposto caráter golpista de João Goulart, que representaria uma ameaça concreta à democracia brasileira, tal qual as forças de direita que assaltaram o poder em 1964. E, ao falar da luta armada, pinta as organizações revolucionárias como assassinos sanguinários e autoritários:

Eu não vi ninguém fazer qualquer mostra de simpatia em relação aos grupos terroristas. Quando eu uso a expressão grupo terrorista, é

(2004) e um sobre o golpe de 1964 (2014). No entanto, o historiador tem produção em diversos campos da história; sua dissertação de mestrado, por exemplo, trata da Revolução Mexicana e sua tese de doutorado, da Guerra de Canudos. 
necessário esclarecer o seguinte: alguém vai dizer assim 'ah, mas é a ditadura que usa a expressão terrorista!' Não é verdade. Basta ler o livro Imagens da revolução, tem documentos ali de grupos que falam que os atentados foram terroristas, grupos de esquerda. E aqueles atentados, você não pode falar em campo democrático, falar que você está fazendo luta política colocando bomba em aeroporto, assassinando pessoas pelas ruas, assaltando banco, matando guarda de banco... isso, que eu saiba, não é luta democrática. O guarda de banco não é um burguês, um inimigo da revolução socialista. E outra coisa é importante ressaltar: em momento algum esses grupos de luta armada colocaram qualquer questão democrática, no sentido das liberdades democráticas. O que esses grupos colocavam era a ditadura do proletariado, ou seja, era se contrapor a uma ditadura impondo outra. Uma era a ditadura do grande capital, a nossa, diriam eles, dos grupos de luta armada, é a ditadura do proletariado. E nós sabemos o que significou a ditadura do proletariado na União Soviética, na Europa oriental, não é? Nós temos amplos conhecimentos disso.

Em seguida, Villa continua se referindo aos riscos que o Brasil correu de cair nas mãos de um governo ditatorial de esquerda:

E o Brasil conseguiu se salvar. Conseguiu se salvar da ditadura militar e graças a Deus também conseguiu se salvar desses grupos. $\mathrm{Eu}$ imagino um desses grupos tomando o poder: eu, por exemplo, não poderia estar falando agora, não é? Porque eu estaria certamente sendo... um paredón ou em qualquer coisa semelhante, já que esses grupos da luta armada nunca conviveram com a diferença. Não só da diferença desses grupos com os outros, como dentro deles. Vários que quiseram romper foram justiçados, hein! É bom lembrar que teve justiçamento de membros da ALN, de outros grupamentos, que acabaram sendo mortos.

Sobre o primeiro aspecto, o também historiador Carlos Fico, em balanço historiográfico, se contrapõe a Villa, apontando que os casos citados por ele para comprovar o suposto golpismo de Goulart (a pressão sobre o Congresso Nacional em duas ocasiões específicas: a votação do adiantamento do plebiscito que decidiria a respeito do regime político do Brasil, em 1962, e a proposição de Estado de Sítio, em 1963) permitiriam, na verdade, falar em "em pressões indevidas, não em golpismo" (Fico, 2017, 9). Para Fico (10), "havia muito jogo político, ameaças, previsões falhas, mas resta por demonstrar a existência de atmosfera de efetiva coerção sob a qual o Congresso teria aprovado a antecipação do plebiscito”. E, sobre as pretensões que Goulart possuiria de se reeleger (algo não previsto legalmente naquele momento), o historiador comenta, novamente, que as afirmações de Villa carecem de evidências empíricas.

No que concerne à luta armada, vale citar as reflexões do sociólogo Marcelo Ridenti (2004, 57), que, debatendo com Reis sobre o uso da denominação resistência para se referir a essas organizações revolucionárias, considera que 
Independentemente da vontade revolucionária das esquerdas armadas, pode-se constatar em retrospecto que elas eram pequenas e frágeis demais para tomar o poder. Fizeram parte do arco amplo e heterogêneo de oposição à ditadura, que pode ser chamado de 'resistência'. As oposições nunca chegaram a se unificar, por vezes havia divergências inconciliáveis entre elas, pois a única afinidade existente era o fim da ditadura.

Já Ipojuca Pontes intervém com maior frequência na parte final de Reparação, quando Moreno opta por extrapolar a discussão sobre a possível injustiça das reparações financeiras oferecidas pelo Estado a Lovecchio e àqueles que plantaram a bomba que o vitimou para discutir o regime comunista cubano, inspiração políticoideológica de muitas das organizações de guerrilha atuantes no Brasil durante a ditadura militar. Nesse segmento, iniciado com o plano de diversas lápides num cemitério, sendo que em uma delas figura uma bandeira de Cuba, o ex-Secretário de Cultura lista atrocidades da ditadura de Fidel Castro, se referindo a ele como "sicário" e "homem diabólico", que não tomaria nenhuma decisão política sem que fosse recompensado financeiramente para tal.

Aqui entra em cena o que parece ser uma motivação política implícita de Moreno com a realização do filme: criticar o PT e o governo Lula (2003-2010), em vigência no momento da realização de Reparação. Tal governo é em parte associado ao passado de luta radical contra a ditadura, já que diversos de seus membros são exguerrilheiros, e também é associado - nesse caso, pelo filme e por discursos politicamente conservadores - a uma suposta continuidade do autoritarismo das esquerdas, por se posicionar como aliado de regimes como o cubano. Esse comentário vem à tona numa determinada fala de Demétrio Magnoli:

Os representantes dos grupos que lutavam contra o regime militar e que hoje chegaram ao poder por meios eleitorais não formam um único grupo, eles participam de grupos diferentes e alguns deles transitaram para uma posição democrática muito clara, ou seja, entre tantos exemplos vamos pegar o exemplo do Fernando Gabeira, que revela isso. Por outro lado, muitos outros mantêm, com algumas oscilações e algumas diferenças, as suas velhas posições stalinistas. Vários deles são admiradores abertos e entusiastas das ditaduras socialistas que restaram, como a ditadura de Fidel Castro, dos Castro, em Cuba.

O caminho argumentativo proposto em Reparação, portanto, liga a luta armada contra a ditadura militar ao autoritarismo comunista de Cuba e da União Soviética e, em seguida, à esquerda brasileira contemporânea, sobretudo ao PT. Moreno acaba, nesse sentido, anunciando uma tendência que, ao menos no cinema, só se manifestaria alguns anos depois, já nos momentos de crise do 
governo de Dilma Rousseff (2011-2016). ${ }^{4}$ Junto à consolidação de um sentimento antipetista em setores consideráveis da sociedade brasileira, vem emergindo um equivalente cinematográfico desde ao menos 2014, inicialmente sob a forma da sátira humorística, nos filmes $O$ candidato honesto (2014), de Roberto Santucci, e Até que a sorte nos separe 3 (2015), de Santucci e Marcelo Antunez, nos quais personagens associados às figuras de Lula e Rousseff encarnam, respectivamente, a corrupção hipócrita e a incompetência administrativa. Posteriormente, em um thriller político como Real O plano por trás da história (2017), de Rodrigo Bittencourt, e no filme policial Polícia Federal - A lei é para todos (2017), de Antunez o primeiro narra o processo de criação e consolidação do Plano Real na perspectiva do economista Gustavo Franco (Emílio Orciollo Neto) e critica duramente o maior partido de esquerda do Brasil através do personagem de um parlamentar petista (Juliano Cazarré), politicamente ignorante e desonesto, enquanto o segundo acompanha o desdobramento da famigerada Operação Lava Jato ${ }^{5}$ tomando Lula (Ary Fontoura) como grande vilão. Também o principal guru intelectual da extrema-direita brasileira contemporânea, Olavo de Carvalho, foi levado ao cinema, tornandose parte constituinte dessa tendência: no documentário $O$ jardim das aflições (2017), de Josias Teófilo, que busca abordar seu pensamento, Carvalho tece comentários negativos sobre o que seria o projeto de poder do PT.

Sobre a vinculação entre anticomunismo e antipetismo no Brasil contemporâneo, Tales Ab'Sáber (2015) observa que tal se dá no encontro do que chama de "homem conservador médio", caracterizado como "antipetista por tradição e anticomunista por

\footnotetext{
${ }^{4}$ Ex-ministra do governo Lula, Dilma Rousseff foi eleita para a presidência da República em 2010, iniciando seu primeiro mandato em janeiro do ano seguinte. A partir de 2013, enfrentou forte oposição em grandes manifestações de rua, que não eram, no entanto, apenas contra seu governo, já que portadoras de pautas difusas. Foi reeleita em 2014, em eleições bastante disputadas e polarizadas contra Aécio Neves, candidato do Partido da Social Democracia Brasileira (PSDB). Após o início de seu segundo mandato, Rousseff e o PT voltaram a ser alvo, agora exclusivo, de grandes manifestações de rua, que contribuíram para o desgaste do governo. Em abril de 2016, foi aprovado na Câmara dos Deputados um pedido de impeachment contra a presidente, processo que foi completado em agosto do mesmo ano, confirmando sua destituição do cargo e empossando o até então vice-presidente, Michel Temer, do Partido da Mobilização Democrática Brasileira (PMDB).

${ }^{5}$ Conjunto de investigações levado a cabo pela Polícia Federal e pelo Ministério Público Federal brasileiros desde março de 2014, visando deslindar e combater relações corruptas entre o poder público e agentes econômicos privados, sobretudo empreiteiros. Altamente midiatizada, a Operação Lava Jato teve um de seus protagonistas, o juiz federal Sérgio Moro, transformado em herói nacional para parcelas da sociedade e levou à prisão importantes lideranças políticas (como o ex-presidente Lula, os ex-ministros petistas José Dirceu e Antônio Palocci e o expresidente da Câmara dos Deputados Eduardo Cunha) e empresariais do país. Além do filme Polícia Federal - A Lei é Para Todos, a operação também foi objeto da série da Netflix O Mecanismo (2018), de José Padilha.
} 
natureza arcaica brasileira mais antiga”, com uma guinada à direita do principal partido de oposição aos governos do PT, o Partido da Social Democracia Brasileira (PSDB), defendida publicamente por Fernando Henrique Cardoso, sua maior liderança. De acordo com Ab’Sáber (2015, 40),

FHC simplesmente sinalizou, em um discurso estranho e novo à leitura política nacional [publicado na revista Interesse Nacional, em 2011], muito assemelhado aos cálculos sociais de marqueteiros americanos, a brecha possível para a emergente tea partização [referência ao movimento norte-americano Tea Party, ligado ao Partido Republicano] do espaço público da política brasileira, um movimento apaixonado de busca de submissão extrema de tudo ao mercado e sua estrita produtividade - jacobinos do mercado - que também animou, em outro círculo do conservadorismo, o delírio arcaico do velho anticomunismo brasileiro. Anticomunistas do nada, velhos autoritários anti-populares e novos tea-partistas em busca de um Estado estrito para a multiplicação de seus negócios, iam de mãos dadas.

O autor produziu essa reflexão buscando as origens de um fenômeno político já tornado relevante em 2015, ano da escrita e publicação do livro Dilma Rousseff e o ódio político e de grandes manifestações contra o governo de Rousseff, eivadas de discursos anticomunistas. No entanto, Reparação explicitou, ainda no final da década anterior, essa associação entre anticomunismo e antipetismo, ainda que em ambiente restrito, para um público reduzido. Trata-se, vale ressaltar, de uma produção independente de Moreno, que, segundo ele, foi financiada com recursos próprios inferiores a 100 mil reais, sem qualquer apoio do poder público ${ }^{6}$ e que não obteve espaço significativo para exibição em festivais ou salas comerciais de cinema.

Moreno reiterou sua postura crítica às esquerdas em seus dois documentários seguintes: Quem Vocês Pensam Que São? (2015), curta-metragem composto por cenas de uma das manifestações pelo impeachment de Rousseff ocorridas em 2015, em São Paulo, e por entrevistas com alguns de seus participantes; e Silenciados (2016), minissérie protagonizada por pais de jovens vítimas de menores infratores e realizada em defesa da redução da maioridade penal no Brasil. A proposta de Silenciados é semelhante à de Reparação, com Moreno escolhendo um tema caro às esquerdas, nesse caso, o debate sobre direitos humanos em meio aos problemas do Brasil na área de segurança pública, e partindo para o ataque. O diretor, no entanto, troca a opção, feita em Reparação, de equilibrar as falas das vítimas da luta armada com as de "especialistas" no assunto pelo predomínio da voz de "gente comum". Só dois "especialistas", advogados que representam posições opostas na discussão sobre a redução da

\footnotetext{
6 “'Reparação' fala sobre vítima das 'vítimas da ditadura”. Disponível em: https://cultura.estadao.com.br/noticias/cinema,reparacao-fala-sobre-vitima-dasvitimas-da-ditadura,498792. Acesso em 13 de janeiro de 2018.
} 
maioridade penal, compõem o painel de entrevistados de Silenciados, e, ainda assim, sua entrada em cena demora para acontecer.

O tom da minissérie é bastante agressivo. Moreno direciona as falas dos entrevistados para a construção de um discurso consensual sobre o quanto as organizações de defesa dos direitos humanos "protegem criminosos" que, por serem menores de idade, não cumprem penas pesadas pelos delitos cometidos. Há diversas referências nesse sentido ao longo de Silenciados. E, como no contexto brasileiro atual há uma sistemática associação entre defender direitos humanos e ser de esquerda, o ataque desferido pelo diretor tem um alvo bem definido.

Já Quem Vocês Pensam Que São? é um filme laudatório em relação às manifestações pró-impeachment, no qual, inclusive, antipetismo e anticomunismo aparecem claramente associados nas falas de alguns dos entrevistados: "você vê o russo, o que ele fez na Ucrânia em 32, eles tiravam a comida das pessoas para elas morrerem de fome... então, a história é longa! Então você vê que existe toda uma formatação para o povo ficar longe disso. Só que tem muita gente que tá aprendendo", diz um deles; "eu não vou deixar que a minha família, que os meus amigos, filhos dos meus amigos, sejam vítimas de um plano de poder de um comunismo", diz outro.

Retornando a Reparação, e pensando especificamente a respeito do tema da luta armada, o filme talvez só se aproxime realmente, no alto grau de criticidade proposto, de As armas. Todos os outros citados anteriormente que de alguma forma apontam problemas nessa opção política, o fazem de forma mais matizada do que Moreno. Em O que é isso, companheiro?, por exemplo, a guerrilha é contraposta à tortura como dois polos extremos, dotados tanto de truculência e violência quanto de dilemas e humanidade, enquanto o centro narrativo é deslocado para a figura do embaixador norteamericano (Bucci, 1997, 221-222); e em O Velho, o comentário de Ferreira Gullar constitui um segmento brevíssimo, que, ainda assim, seu diretor viu como suficientemente problemático para alguns anos depois realizar outro filme que se aproximava com maior empatia dos guerrilheiros.

Ainda no terreno das continuidades, Reparação guarda certas semelhanças com dois outros filmes: Pra frente Brasil e O Velho. Com o primeiro, ao apresentar a história de Marlio Jesus da Silva e seu irmão, jovens comuns vitimados pela tortura e pelo extremismo político da época sem que de fato tomassem parte nele. Ganha força aqui a chamada "teoria dos dois demônios", segundo a qual teria havido durante a ditadura militar o embate entre dois extremos equivalentes, igualmente violentos e autoritários, que acabaram por atingir também quem estava no meio deles, alheio a essa "guerra". Reis $(2014,134)$ critica essa perspectiva, ao apontar que "fazia-se aí a economia de uma gritante evidência: não houvera guerra alguma, e 
sim um enfrentamento extremamente desigual entre um poderoso Estado e suas Forças Armadas contra alguns milhares de revolucionários e seus simpatizantes".

Essa leitura também ecoa a fala de Ferreira Gullar no documentário de Toni Venturi e é verbalizada por Magnoli em determinado momento de Reparação:

normalmente a luta armada, principalmente nas formas da guerrilha, tende a fazer com que a repressão dos Estados autoritários recaia principalmente não sobre os guerrilheiros, mas sobre a população que está no seu entorno e que não tem os meios que os guerrilheiros têm de se proteger das medidas do Estado. Então, do ponto de vista político, as vítimas principais, na maioria dos casos, de ação guerrilheira não são os guerrilheiros, são a população.

\section{Conclusão}

Trata-se, enfim, do exemplar de um cinema claramente de direita, algo que Moreno assume publicamente, ao menos em tempos mais recentes. Em entrevista à revista semanal Época sobre Silenciados, criticou a "agenda de esquerda" do cinema brasileiro, que "patrulharia" quem nela não se encaixa, dizendo não se incomodar de ser tachado de "conservador" ou "reacionário", uma vez que os cineastas de esquerda não se envergonham de se assumir “comunistas", defensores de uma ideologia responsável por milhões de mortes: "Não me importo. Acho engraçado um cineasta ser chamado de comunista, todo mundo acha bonito. Morreram 200 milhões de pessoas por causa da ideologia da qual o cara se declara seguidor, e as pessoas acham bonito".

Nesse sentido, Moreno se diferenciaria dos diretores de Real O plano por trás da história e Polícia Federal - A lei é para todos, que buscam afastar qualquer pecha política de seus filmes. Bittencourt, em entrevista ao portal Adoro Cinema, ressaltou o que seria, para ele, um aspecto positivo de Real: "esse filme é sobre uma grande ideia que foi o Plano Real, ele não é político. Eu não sou um sujeito político, eu sou um artista. O que eu quis com esse filme foi passar a ideia do Plano Real". 8 á Antunez reconheceu, para o mesmo portal, a presença da política em Polícia Federal, ainda que se esquivando de atribuir à obra qualquer posicionamento claro sobre os temas abordados: "o tema é político, tudo que está se desdobrando é político. Mas, na verdade, embora a história seja política, a gente

\footnotetext{
${ }^{7}$ Entrevista disponível em: http://epoca.globo.com/vida/noticia/2016/03/ocinema-nacional-tem-uma-agenda-de-esquerda-afirma-daniel-moreno.html. Acesso em 13 de janeiro de 2018.

${ }^{8}$ Entrevista disponível em: http://www.adorocinema.com/personalidades/personalidade572953/entrevistas/?cmedia=19555208. Acesso em 13 de janeiro de 2018.
} 
optou por não ficar fazendo análise no filme sobre a questão política".

Ambos omitem, portanto, o gesto político presente na caracterização depreciativa dos personagens petistas, que, num contexto de forte polarização e disseminação do antipetismo, se torna ainda mais emblemática. Algo que Moreno, no entanto, também se aproximou de fazer quando das primeiras exibições de Reparação, em 2010, ao ser entrevistado pelo jornal O Estado de $S$. Paulo e pela Veja.com. Na primeira entrevista, o diretor buscou ressaltar o caráter apartidário de seu filme, que teria, como principal objetivo, "ampliar as discussões sobre direitos humanos": "não partidarizei o meu filme e não cito casos particulares das inúmeras distorções que existem quanto à concessão de indenizações". ${ }^{10} \mathrm{Na}$ segunda, se definiu como não sendo um cineasta político e destacou o que entende como uma abertura ao aprendizado existente em Reparação, em contraponto à maioria dos filmes feitos sobre a ditadura militar, que serviriam a um projeto de doutrinação esquerdista: "diferentemente de alguns cineastas, eu não fiz o filme para ensinar nada, para doutrinar ou para conscientizar o povo a respeito da revolução, nada disso. Eu fiz o filme para aprender a respeito de alguma coisa".

Talvez seja possível perceber no diretor, portanto, uma radicalização de seus posicionamentos, ocorrida de forma concomitante à intensificação da polarização política no país. Nesse sentido, enquanto no contexto do lançamento de Reparação ele manteve postura pública moderada, transparecendo buscar alguma neutralidade no tratamento do tema da luta armada (ainda que não haja no documentário nenhuma voz dissonante, que de alguma forma se contraponha às falas dos entrevistados "especialistas", sempre críticas às esquerdas), ao realizar Quem Vocês Pensam Que São? se engajou abertamente no processo político brasileiro, e, com Silenciados, defendeu sem meios termos a redução da maioridade penal. E mesmo a composição estética de seus filmes explicita essa radicalização: ao uso relativamente discreto, pelo primeiro, de elementos da linguagem cinematográfica, se contrapõem as opções por uma trilha sonora dedicada a comentar e acentuar as emoções dos entrevistados em Silenciados e Quem Vocês Pensam Que São? e pela câmera lenta como meio para tornar épico e sublime o evento registrado nesse último.

\footnotetext{
${ }^{9}$ Entrevista disponível em: http://www.adorocinema.com/personalidades/personalidade732276/entrevistas/?cmedia=19556174. Acesso em 13 de janeiro de 2018 .

${ }^{10}$ Disponível em: https://cultura.estadao.com.br/noticias/cinema,reparacao-falasobre-vitima-das-vitimas-da-ditadura,498792. Acesso em 13 de janeiro de 2018.
} 


\section{BIBLIOGRAFIA}

Ab’Sáber, Tales. Dilma Rousseff e o ódio político. São Paulo: Hedra, 2015.

Araújo, Maria Paula. 2008. "Esquerdas, juventude e radicalidade na América Latina nos anos 1960 e 1970". In Ditadura e democracia na América Latina: balanço histórico e perspectivas, Carlos Fico et. al.. Rio de Janeiro: Editora FGV.

Bordwell, David. 2008. Figuras traçadas na luz: a encenação no cinema. Campinas, SP: Papirus.

Bucci, Eugênio. 1997. "O deslocamento do narrador em O que é isso, companheiro?”. In Versões e ficções: o sequestro da história, Daniel Aarão Reis et al.. São Paulo: Editora Fundação Perseu Abramo.

Campo, Mônica Brincalepe. 2011. "O Desafio: filme reflexão no pós1964". In História e cinema: dimensões históricas do audiovisual, Maria Helena Capelato et al.. $2^{\mathrm{a}}$ ed. São Paulo: Alameda.

Fernandes, Fernando Seliprandy. 2013. "O monumental e o íntimo: dimensões da memória da resistência no documentário brasileiro recente”. Estudos Históricos, Rio de Janeiro, vol. 26, $\mathrm{n}^{\mathrm{o}} 51$ (janeiro-junho): 55-72.

Ferro, Marc. 2010. Cinema e História. São Paulo: Paz e Terra.

Fico, Carlos. 2017. "Ditadura militar brasileira: aproximações teóricas e historiográficas". Revista Tempo e Argumento, Florianópolis, v. 9, n. 20 (jan./abr): 5-74.

Guedes, Wallace Andrioli. 2016. "Política como produto: Pra frente Brasil e o cinema de Roberto Farias." Tese de Doutorado, Universidade Federal Fluminense, Instituto de Ciências Humanas e Filosofia. Departamento de História.

—_—. 2014. "Reflexões sobre a representação da esquerda armada no cinema brasileiro". Revista Contemporânea, do Núcleo de Estudos Contemporâneos da Universidade Federal Fluminense.

Oricchio, Luiz Zanin. 2003. Cinema de novo: um balanço crítico da Retomada. São Paulo: Estação Liberdade.

Reis, Daniel Aarão, Marcelo \& Motta Ridenti e Rodrigo Patto Sá. 2004. O golpe e a ditadura militar, quarenta anos depois (19642004). Bauru, SP: EDUSC.

Ridenti, Marcelo. 2004. "Resistência e mistificação da resistência armada contra a ditadura: armadilhas para os pesquisadores". In $O$ golpe e a ditadura militar, quarenta anos depois (19642004), Daniel Aarão Reis, Marcelo \& Motta Ridenti, Rodrigo Patto Sá. Bauru, SP: EDUSC. 
Rollemberg, Denise. 2001. O apoio de Cuba à luta armada no Brasil: o treinamento guerrilheiro. Rio de Janeiro: Mauad.

Villa, Marco Antonio. 2004. Jango, um perfil (1945-1964). 1. ed. São Paulo: Globo.

———. 2014. Ditadura à brasileira: a democracia golpeada à esquerda e à direita. Rio de Janeiro: Leya Casa da Palavra.

Xavier, Ismail. 2012. Alegorias do subdesenvolvimento: cinema novo, tropicalismo, cinema marginal. São Paulo: Cosac \& Naify.

\section{FILMOGRAFIA}

As armas [longa-metragem] Dir. Astolfo Araújo. Data Filmes, Brasil, 1969. 85 mins.

Até que a sorte nos separe 3 [longa-metragem] Dir. Roberto Santucci e Marcelo Antunez. Globo Filmes et. al., Brasil, 2015. 106 mins.

Brazil, a report on torture [longa-metragem] Dir. Haskell Wexler e Saul Landau. EUA, 1971. 60 mins.

Cabra-cega [longa-metragem] Dir. Toni Venturi. Olhar Imaginário, Brasil, 2004. 107 mins.

Diário de uma busca [longa-metragem] Dir. Flávio Castro. Les Films du Poisson et. al., Brasil/França, 2010. 108 mins.

Em busca de Iara [longa-metragem] Dir. Flávio Frederico. Kinoscopio et. al., Brasil, 2013. 91 mins.

Em nome da segurança nacional [longa-metragem] Dir. Renato Tapajós. Tapiri Cinematográfica, Brasil, 1983. 48 mins.

Hércules 56 [longa-metragem] Dir. Sílvio Da-Rin. Antonioli \& Amado Produções, Brasil, 2006. 93 mins.

Jango [longa-metragem] Dir. Sílvio Tendler. Caliban Produções Cinematográficas et. al., Brasil, 1984. 115 mins.

Lamarca [longa-metragem] Dir. Sérgio Rezende. Morena Filmes et. al., Brasil, 1994. 130 mins.

Marighella [longa-metragem] Dir. Isa Grinspum Ferraz. Mar Aberto Audiovisual et. al., Brasil, 2012. 100 mins.

O bom burguês [longa-metragem] Dir. Oswaldo Caldeira. Encontro Produções Cinematográficas, Brasil, 1983. 99 mins.

$O$ candidato honesto [longa-metragem] Dir. Roberto Santucci. Panorama Filmes/Camisa Listrada, Brasil, 2014. 110 mins.

O desafio [longa-metragem] Dir. Paulo César Saraceni. Mapa Filmes et. al., Brasil, 1965. 81 mins. 
O Evangelho segundo Teotônio [longa-metragem] Dir. Vladimir Carvalho. Fundação Pedroso Horta et. al., Brasil, 1984. 90 mins.

O jardim das aflições [longa-metragem] Dir. Josias Teófilo. Lavra Filmes, Brasil, 2017. 81 mins.

O que é isso, companheiro? [longa-metragem] Dir. Bruno Barreto. Columbia Pictures et. al., Brasil/EUA, 1997. 110 mins.

O velho - A história de Luiz Carlos Prestes [longa-metragem] Dir. Toni Venturi. Olhar Imaginário/ Casa de Produção, Brasil, 1997. 104 mins.

Os anos JK [longa-metragem] Dir. Sílvio Tendler. Terra Filmes, Brasil, 1980. 110 mins.

Os dias com ele [longa-metragem] Dir. Maria Clara Escobar. Filmes de Abril et. al., Brasil, 2013. 105 mins.

Polícia Federal - A lei é para todos [longa-metragem] Dir. Marcelo Antunez. Downtown Filmes et. al., Brasil, 2017. 107 mins.

Pra frente Brasil [longa-metragem] Dir. Roberto Farias. Embrafilme/ Produções Cinematográficas R. F. Farias Ltda. et. al., Brasil, 1982. 105 mins.

Que bom te ver viva [longa-metragem] Dir. Lúcia Murat. Taiga Produções et. al., Brasil, 1989. 110 mins.

Quem Vocês Pensam Que São? [curta-metragem] Dir. Daniel Moreno. Terranova Filmes, Brasil, 2015. 11 mins.

Real - O plano por trás da história [longa-metragem] Dir. Rodrigo Bittencourt. Lighthouse et. al., Brasil, 2017. 96 mins.

Reparação [longa-metragem] Dir. Daniel Moreno. Terranova Filmes, Brasil, 2009. 95 mins.

Silenciados [longa-metragem] Dir. Daniel Moreno. Terranova Filmes, Brasil, 2016. 204 mins.

Terra em transe [longa-metragem] Dir. Glauber Rocha. Mapa Filmes, Brasil, 1967. 111 mins.

Você também pode dar um presunto legal [filme amador] Dir. Sérgio Muniz. Brasil, 1971/2006. 39 mins.

Recebido em 15-01-2018. Aceite para publicação em 10-07-2018. 